\title{
ANALISIS KETERAMPILAN LITERASI INFORMASI PUSTAKAWAN PUSAT INFORMASI ILMIAH DI LINGKUNGAN UNIVERSITAS JENDERAL SOEDIRMAN PURWOKERTO BERDASARKAN MODEL THE BIG 6
}

\author{
Hendra Wicaksono $^{1 *)}$, Aris Kurniawan ${ }^{2 *}$ \\ ${ }^{1}$ Program Studi Ilmu Perpustakaan Universitas YARSI \\ ${ }^{2}$ UPT Perpustakaan Universitas Jendral Soedirman \\ *)Korespondensi: ${ }^{1}$ hendra.wicaksono@yarsi.ac.id, ${ }^{2}$ ariskurniawanlib@ gmail.com
}

\begin{abstract}
[Title: Information Literacy Skills Analysis of Scientific Information Center Librarian in The University of Jendral Soedirman Purwokerto Based On The Big 6 Model]This study analyzes the information literacy skills of librarians in the Pusat Informasi Ilmiah in Jenderal Soedirman University based models The Big6. This research includes the study population because the entire population is a librarian at Pusat Informasi Ilmiah in Jenderal Soedirman University that meet the criteria of sampled. The study population was the entire librarian or library staff and 12 faculty who have a background in the field of library science and librarianship or getting training, which amounted to 18 people. Data obtained by distributing questionnaires in the validity and reliability of the instrument. Acquisition of questionnaire data later in the tabulation transferred in the form of a percentage. Percentage yield further analyzed and interpreted. The results showed that nearly half the librarians have the skills in defining the problem is characterized by $44 \%$.. Most have skills of information search strategy marked $56 \%$. Half have found the skills of information access locations are marked 50\%. Almost half the librarians have the skills or the information search strategies have an effective way to filter and extract information marked 33\%. Most have skills synthesis or combining various information marked 61\%. Most librarians are skilled in providing an assessment of results and processes that have successfully gone through marked $61 \%$.
\end{abstract}

Keywords: information literacy; librarians

\begin{abstract}
Abstrak
Penelitian ini menganalisis keterampilan literasi informasi pustakawan Pusat Informasi Ilmiah di lingkungan Universitas Jenderal Soedirman berdasarkan model The Big6. Penelitian ini termasuk penelitian kualitatif karena seluruh populasi pustakawan di Pusat Informasi Ilmiah di lingkungan Universitas Jenderal Soedirman yang memenuhi kriteria dijadikan sampel. Populasi penelitian ini adalah seluruh pustakawan dan atau petugas perpustakaan di 12 Fakultas yang memiliki latar belakang bidang ilmu perpustakaan dan atau pernah mengikuti pelatihan kepustakawanan, yaitu berjumlah 18 orang. Data diperoleh dengan melakukan penyebaran kuesioner yang di uji validitas dan reliabilitas instrumennya. Perolehan data kuesioner kemudian di tabulasi dalam bentuk persentase. Hasil persentase selanjutnya dianalisis dan diinterpretasikan. Hasil penelitian menunjukkan bahwa, hampir setengah pustakawan memiliki keterampilan dalam mendefinisikan masalah ditandai dengan 44\%. Sebagian besar memiliki keterampilan strategi pencarian informasi ditandai 56\%. Setengah memiliki keterampilan menemukan lokasi akses informasi ditandai 50\%. Hampir setengah pustakawan memiliki keterampilan strategi pencarian informasi atau memiliki cara yang efektif untuk menyaring dan memeras informasi ditandai 33\%. Sebagian besar memiliki keterampilan sintesis atau menggabungkan berbagai informasi ditandai $61 \%$. Sebagian besar pustakawan memiliki keterampilan dalam memberikan penilaian terhadap hasil dan proses yang sudah berhasil dilaluinya ditandai $61 \%$.
\end{abstract}

Kata kunci: literasi informasi; pustakawan 


\section{Pendahuluan}

Ledakan informasi menuntut masyarakat untuk memiliki keterampilan dalam mencari, menemukan, menganalisis, mengevaluasi, serta mengkomunikasikan informasi yang berfungsi dalam memenuhi kebutuhan informasi guna memecahkan berbagai macam masalah. Keterampilan tersebut selanjutnya oleh para ahli disebut dengan istilah information literacy yang dalam bahasa Indonesia lebih dikenal dengan istilah literasi informasi (Septiyantono, 2015). Literasi informasi mencakup pengetahuan dan kebutuhan informasi seseorang dan kemampuan untuk mengenali, mengetahui lokasi, mengevaluasi, mengorganisasi dan menciptakan, menciptakan dan mengkomunikasikan informasi secara efektif untuk mengatasi isu atau masalah yang dihadapi seseorang (Basuki. 2013).

Meskipun saat ini informasi melimpah, tidak semuanya dapat digunakan dan dimanfaatkan sepenuhnya. Ada beberapa aspek yang harus dipenuhi oleh informasi agar dapat digunakan dan dimanfaatkan. Menurut Tata Sutabri (2005) Kualitas suatu informasi tergantung dari tiga hal yaitu, informasi harus akurat (Accurate), tepat waktu (Timeliness), dan relevan (Relevance). Informasi yang digunakan dan dimanfaatkan hingga termanifestasikan dalam bentuk pengambilan keputusan atau pemecahan masalah adalah perwujudan proses literasi informasi.

Perkembangan penyebaran informasi mempunyai trend sendiri melalui berbagai media, pustakawan dituntut untuk senantiasa ikut serta mengikuti. Sinergitas teknologi informasi dan komunikasi dengan bidang ilmu perpustakaan berdampak pada ragam variasi pekerjaan yang harus dilakukan oleh pustakawan. Pustakawan senatiasa harus berubah dan berorientasi ke depan, menjadi pustakawan modern yang dapat menjembatani masa transisi. Antara menyediakan layanan berbentuk cetak maupun non cetak disertai dengan kemampuan untuk mengatur strategi penelusuran secara cepat dan tepat (Qalyubi, 2007).

Pustakawan dituntut mampu menyesuaikan diri dengan karakteristik pemustakanya dengan senantiasa meningkatkan keterampilan dan kemampuannya. Pemustaka perpustakaan perguruan tinggi didominasi oleh kaum intelektual yang yang akrab dengan teknologi informasi. Mereka mempunyai penguasaan yang baik dalam memanfaatkan teknologi informasi dan komunikasi seperti internet atau media non cetak. Hal tersebut akan berimbas pada tuntutan layanan perpustakaan perguruan tinggi. Ketimpangan penguasaan teknologi informasi dan komunikasi antara pemustaka dengan pustakawan akan menjatuhkan kredibilitas pustakawan. Dengan kata lain, pustakawan harus memiliki keterampilan untuk mengidentifikasi, mencari, mengevaluasi, dan mempresentasikan informasi atau lebih dikenal dengan istilah literasi informasi.

Pusat informasi ilmiah Universitas Jenderal Soedirman merupakan manifestasi dari perpustakaan. Pusat informasi Ilmiah berada di setiap fakultas di lingkungan Universitas Jenderal Soedirman. Tidak jauh berbeda dengan perpustakaan pada umumnya tugas pokok dan fungsi Pusat Informasi Ilmiah sama dengan perpustakaan. Pusat Informasi Ilmiah Universitas Jenderal Soedirman memiliki pustakawan yang berlatar belakang pendidikan ilmu perpustakaan. Oleh karena itu para pustakawan di tuntut untuk menguasai keterampilan-keterampilan dalam mengelola informasi, salah satunya adalah menguasai 
literasi informasi, karena dengan menguasai literasi informasi akan membantu pustakawan dalam memberikan informasi yang relevan dan berkualitas sesuai kebutuhan pemustaka.

Berdasarkan gambaran di atas penulis tertarik untuk melakukan penelitian tentang "Analisis Keterampilan Literasi Informasi Pustakawan Pusat Informasi Ilmiah Di Lingkungan Universitas Jenderal Soedirman Berdasarkan Model The Big6", untuk mengetahui keterampilan literasi informasi pustakawan Pusat Informasi Ilmiah di lingkungan Universitas Jenderal Soedirman dengan menggunakan model The Big6. Tujuan dari penelitian ini adalah untuk mengetahui bagaimana keterampilan literasi informasi pustakawan Pusat Informasi Ilmiah di lingkungan Universitas Jenderal Soedirman dalam hal mendefinisikan masalah informasi, menemukan strategi informasi pencarian informasi, menentukan lokasi dan akses informasi, menggunakan informasi, mensintesis informasi dan mengevaluasi informasi.

\section{Landasan Teori}

\subsection{Konsep dan Definisi Literasi Informasi}

Literasi informasi diperkenalkan pertama kali oleh Paul Zurkowski pada tahun 1974. Paul Zurkowski (The President of Information Industry Association of United States) dalam proposal yang diajukannya kepada National Commision on Libraries and Information Science mengemukakan bahwa didalam program nasional salah satu yang harus dicapai adalah literasi informasi secara universal. Zurkowski berpendapat bahwa seseorang yang terlatih dalam menggunakan sumber-sumber informasi dalam menyelesaikan tugas mereka disebut orang yang melek informasi karena mereka telah belajar teknik menggunakan informasi dengan baik dan keterampilan dalam menggunakan beragam alat informasi.

The UK's Chartered Institute of Library and Information Professionals (CILIP) membuat satu definisi pada tahun 2005 yang lebih singkat dari definisi lainnya bahwa literasi informasi adalah mengetahui kapan dan kenapa kita membutuhkan informasi, mengetahui dimana kita dapat menemukan dan bagaimana mengevaluasinya, serta dapat menggunakan dan mengkomunikasikannya sesuai etika (Amstrong, 2005).

Dari berbagai pendapat di atas penulis membuat kesimpulan bahwa literasi informasi adalah suatu pemahaman atau kemampuan untuk mengidentifikasi, mencari, menemukan, menempatkan, mengorganisir, mengevaluasi, menilai, meneliti, menyesuaikan dan menggunakan, menciptakan, mengkomunikasikan dan menemukan kembali informasi termasuk pemahaman bagaimana bahan pustaka ditata, akrab dengan sumber daya yang tersedia (termasuk bentuk informasi dan perkakas pencarian otomatis), dan pengetahuan tentang teknik yang biasa digunakan secara efektif, secara efisien dan secara etis untuk tujuan yang dimaksud. 


\subsection{Kriteria Literasi Informasi}

Guna memenuhi kebutuhan seseorang untuk mencapai tujuan, keputusan dan atau menyelesaikan masalah keteramiplan literasi informasi sangat dibutuhkan. Terdapat beberapa kriteria dalam literasi informasi, menurut Breivik dalam Kuhlthau (1987), kriteria literasi informasi sebagai berikut

a. Skill and knowledge (kemampuan dan pengetahuan)

Literasi informasi dimulai dengan sebuah pengetahuan mengenai sumber informasi dan peralatan dalam memperoleh informasi misal indeks untuk mengakses informasi. Kemampuan dibutuhkan untuk menentukan strategi dan teknik apa yang digunakan dalam mengakses informasi ketika informasi dibutuhkan.

b. Attitudes (Sikap)

Karakteristik yang kedua adalah sikap. Sikap ini meliputi ketekunan, perhatian secara detail dan keragu-raguan (misalnya penyebab menerima informasi yang diperoleh).

c. Time and labor intensive (waktu dan intensitas penggunaan)

Salah satu karakteristik yang paling penting adalah waktu dan penggunaan informasi. Kegunaan dari kemampuan ini adalah untuk mengetahui apakah informasi digunakan secara efektif atau tidak.

d. Need driven (pengendali kebutuhan)

Maksudnya adalah bagaimana seseorang mengidentifikasi informasi yang akan dicari dan bagaimana memecahkan masalah dalam pencarian dan penggunaan informasi.

e. Computer literacy (literasi komputer)

Karakteristik yang dibutuhkan dalam mendukung kemampuan literasi yaitu bagaimana menggunakan teknologi komputer dalam mencari informasi.

Menurut Shapiro dalam Pendit (2007) bahwa terdapat 7 (tujuh) keterampilan yang dibutuhkan dalam era digital yaitu :

a. Tool literacy

Kemampuan memahami dan menggunakan teknologiinformasi secara konseptual dan praktikal, termasuk di dalamnyakemampuan menggunakan perangkat lunak, keras, multimediayang relevan dengan bidang kerja atau studi.

b. Resources literacy

Kemampuan memahami bentuk, format, lokasi,dan cara mendapatkan sumber daya informasi terutama jaringaninformasi yang terus berkembang

c. Social structural literacy

Pemahaman tentang bagaimana informasi dihasilkan oleh berbagai pihak di dalam sebuah masyarakat.

d. Research literacy 
Yaitu kemampuan menggunakan peralatan berbasis teknologi informasi sebagai alat riset.

e. Publishing literacy

Kemampuan untuk menyusun dan menerbitkan publikasi dan ide ilmiah ke kalangan masyarakat dengan memanfaatkan komputer dan internet.

f. Emerging technology literacy

Kemampuan yang memungkinkan seseorang untuk terus menerus menyesuaikan diri dan mengikuti perkembangan tekhnologi dan bersama-sama dengan komunitasnya ikut menentukan arah pemanfaatan tekhnologi informasi untuk kepentingan pengembangan ilmu.

g. Critical literacy

Kemampuan melakukan evaluasi secara kritis terhadap untung rugi menggunakan teknologi telematika dalam kegiatan ilmiah.

Apabila kriteria diatas dapat terpenuhi oleh seseorang maupun suatu negara maka tingkat keterpakaian terhadap informasi akan tinggi dan tidak ada lagi yang buta informasi. Pustakawan mempunyai peranan untuk membantu memenuhi kriteria tersebut. Oleh karena itu pustakawan juga harus paham kriteria tersebut dan menguasai literasi informasi.

\subsection{Keterampilan Literasi Infromasi}

Menurut Gunawan (2008) ada 7 (tujuh) langkah dalam memperoleh kemampuan literasi informasi. Tujuh langkah keterampilan tersebut adalah:

a. Merumuskan masalah

Langkah awal dalam perumusan masalah adalah mengidentifikasi masalah. Langkah-langkah dalam perumusan masalah adalah:

1) Melakukan analisis situasi

Analisis situasi adalah mencari informasi yang dapat diperoleh melalui perpustakaan, toko buku, internet dan pusat-pusat informasi lainnya.

2) Brainstroming

Brainstroming adalah teknik yang digunakan dalam mengembangkan dan menciptakan ide-ide baru untuk penyelesaian suatu masalah.

3) Mengajukan pertanyaan

Kegiatan ini bertujuan untuk mendorong berpikir secara kritis.

4) Memvisualisasikan pemikiran (mind mapping)

Kegiatan memvisualisasikan pemikiran dilakukan dengan penggambaran hubungan diantara konsep-konsep.

b. Mengidentifikasi sumber informasi 
Sumber-sumber informasi terdiri dari sumber informasi tercetak (buku, jurnal, majalah, laporan penelitian) dan sumber elektronik (melalui internet yaitu jurnal elektronik, buku elektronik, dan informasi-informasi elektronik lainnya). Ada beberapa kriteria penilaian sumber informasi:

1) Relevansi

Relevansi adalah menilai sejauh mana informasi yang dikandung sesuai dengan topik yang dibahas dan dapat dilihat dari kedalaman dan sumber referensi yang jelas.

2) Kredibilitas

Kredibilitas adalah menentukan sejauh mana sumber informasi dapat dipercaya.

3) Kemuktahiran

Kemutakhiran sumber informasi dapat dilihat dari tahun terbit, keterangan kapan revisi terakhir kali, keterangan kapan revisi secara berkala dan daftar pustaka. Sedangkan kalau melalui sumber internet, kemutakhiran dapat dilihat kapan situs tersebut dibuat dan kapan terakhir kali di up date.

c. Mengakses informasi

Langkah langkah dalam mengakses informasi adalah:

1) Mengetahui kebutuhan informasi

2) Mengidentifikasi alat penelusuran yang relevan seperti di perpustakaan OPAC, Katalog, WEBPAC dan di internet seperti search engine, meta search engine.

3) Menyusun strategi penelusuran misalnya dengan operator boolean.

d. Menggunakan informasi

Sumber informasi yang ditawarkan di era globalisasi informasi sangat banyak tetapi belum semua informasi tersebut sesuai dengan kebutuhan informasi. Sehingga perlu melakukan seleksi terhadap informasi dengan kriteria sebagai berikut:

1) Relevan

Informasi dikatakan relevan jika sesuai dengan masalah yang dibahas.

2) Akurat

Informasi yang akurat adalah informasi yang tidak menyesatkan. Sehingga untuk membutikannya perlu diperiksa terlebih dahulu.

3) Objektif Suatu karya dikatakan objektif apabila berdasarkan fakta dan fenomena yang dapat diamati.

e. Menciptakan karya

Penciptaan suatu karya harus berdasarkan persyaratan COCTUC yaitu:

1) Clarifity (kejelasan)

Suatu karya ditulis harus berdasarkan langkah-langkah, tidak berbelit- belit/langsung ke topik permasalahan, disusun secara logis dan menggunakan sudut pandang yang konsisten.

2) Organization (organisasi) 
Pengorganisasian suatu karya dilakukan dengan cara penyusunan ide- ide yang akan dibahas dalam karya tersebut.

3) Coherence (koherensi dan pertalian)

Pertalian suatu karya dapat dilihat dari hubungan yang jelas antara ide-ide maupun gagasangagasan yang dibahas dalam topik tersebut.

4) Transision (transisi)

Transisi diperlukan agar suatu informasi mudah dimengerti. Transisi disebut juga dengan penghubung. Transisi dibuat antara kalimat- kalimat, paragraf ke paragraf dan ide ke ide. Transisi juga bisa dilakukan dengan menggunakan kata ganti.

5) Utility (kesatuan)

Suatu karya yang baik adalah apabila memiliki satu kesatuan misalnya kalimat demi kalimat dan paragraf demi paragraf.

6) Conciseness (kepadatan)

Kepadatan suatu karya dapat dilakukan dengan cara menghindari penggunan kata-kata atau frasefrase berlebihan dan berbelit-belit.

Plagiarisme merupakan hal yang harus dihindari dalam menciptakan suatu karya. Hal ini dilakuka $n$ dengan mencantumkan sumber informasi yang diambil setiap kali digunakan.

f. Mengevaluasi

Kegiatan mengevaluasi suatu karya dapat dilakukan dengan membaca karya yang akan dievaluasi. Kita harus membaca secara teliti agar dapat melihat kesalahan-kesalahan yang mungkin timbul baik pada bagian pendahuluan, isi dan penutup.

g. Menarik pelajaran

Pelajaran dapat diperoleh berdasarkan kesalahan-kesalahan, kegagalan- kegagalan dan pengalaman baik pengalaman sendiri maupun orang lain. Pelajaran ini juga dilakukan dengan membuat sebuah catatan mengenai apa saja yang telah dilakukan dan dipelajari

Hal yang sama juga dijabarkan oleh Campbell dalam Jesus (2008:11) bahwa ada beberapa langkahlangkah dalam memperoleh kemampuan literasi informasi yaitu:

h. Merumuskan kebutuhan informasi

Merumuskan kebutuhan informasi merupakan tahap awal dalam melakukan penelusuran informasi. Kegunaan dari indentifikasi informasi adalah seseorang akan mengetahui apa kegunaan informasi yang dicari misalnya untuk pendidikan, kesehatan dan hubungan dengan masyarakat.

i. Mengalokasikan dan mengevaluasi kualitas informasi.

Mengalokasikan informasi dapat dilakukan dengan cara manual atau pun membuatnya ke dalam database agar suatu saat diperlukan bisa ditemu kembali. Kualitas dari informasi dapat dilihat dari penggunaan informasi tersebut dan kredibilitas dari informasi tersebut. Apabila kriteria informasi dipenuhi oleh suatu informasi maka kualitasnya semakin baik. 
j. Menyimpan dan menemu kembalikan informasi.

Seseorang harus mampu menyimpan informasi yang sudah diperoleh agar suatu saat informasi tersebut mudah ditemukan kembali ketika akan digunakan. Penyimpanan dapat dilakukan dengan menggunakan sistem manual maupun elektronik. Sistem manual dapat dilakukan dengan menggunakan rak-rak perpustakaan sedangkan sistem elektronik dapat dilakukan dengan menggunakan komputer.

k. Menggunakan informasi secara efektif dan efisien.

Kemampuan ini digunakan agar seseorang mampu menggunakan informasi yang diperoleh secara efektif dan efisien.

1. Mengkomunikasikan pengetahuan.

Kemampuan ini bertujuan untuk memampukan seseorang dalam menciptakan pengetahuan baru dan menyebarkan atau mengkomunikasikan kepada orang lain yang membutuhkan informasi tersebut.

Berdasarkan pendapat di atas, maka untuk memperoleh keterampilan literasi informasi seseorang harus menguasai dan mempelajari tahapan demi tahapan. Apabila tahapan demi tahapan literasi informasi tersebut dikuasai maka akan semakin mempermudah untuk memperoleh keterampilan literasi informasi.

\subsection{Model Literasi Informasi The Big6}

Model Literasi Informasi banyak digunakan di sekolah dan di lembaga pendidikan adalah the Big6. The Big6 dikembangkan oleh 2 orang professor di bidang ilmu informasi dari Universitas Syracusse. Dari penelitian dan pengamatan mereka selama puluhan tahun itulah maka lahirlah sebuah rumusan yang agak berbeda dengan beberapa model Literasi Informasi yang sudah dibuat sebelumnya seperti model Kulthau dan Strippling misalnya.

Keunikan dari model the Big6 ini antara lain adalah karena model ini di klaim oleh pembuatnya sebagai sebuah model "problem solving" dalam menyelesaikan masalah informasi. Model ini sifatnya lebih fleksibel dari model-model literasi informasi lainnya, karena model ini bisa diterapkan pada hampir semua masalah manusia yang berkaitan dengan pengambilan keputusan yang menggunakan informasi sebagai dasar pengambilan keputusan.

The Big6 memiliki 6 keterampilan dan setiap keterampilan diperjelas dengan 2 subdivisi. Keenam keterampilan tersebut adalah:

a. Task Definition/Mendefinisikan masalah.

Tahap ini diawali dengan mendefinisikan masalah secara menyeluruh. Step pertama ini terdiri dari 2 subdivisi sbb:

1) Definisikan permasalahannya.

Dalam penulisan, maka tahap ini adalah penentuan topik dan menjelaskan pertanyaan riset (Research Question). Cara yang digunakan untuk mendapatkan topic, misalnya dengan cara : brainstorming menggunakan $5 \mathrm{~W}-1 \mathrm{H}$, free writing, dan lain sebaginya. 
2) Mengidentifikasi kebutuhan informasi.

Membatasi kebutuhan informasi pada apa yang menjadi persoalan, seperti mendaftarkan semua "keyword" yang berhubungan dengan topic yang dipilih. Misalnya dengan menggunakan "mind mapping".

b. Information Seeking Strategies/ Strategi pencarian informasi.

Dalam tahap ini akan dibatasi informasi apa yang akan dicari, termasuk didalamnya membatasi perencanaan terhadap sumber-sumber informasi yang dicari. Minimal yang menjadi criteria penyeleksian sumber, adalah : otritatif, kebaruan, dan akurasi. Subdivisi dari tahap 2 ini adalah:

1) Melakukan brainstorm terhadap semua sumber informasi pendukung yang mungkin untuk digunakan.

Perlu didukung dengan kepemilikan wawasan yang luas terhadap berbagai sumber informasi, baik yang tersedia di perpustakaan, ataupun sumber-sumber yang bersifat primer seperti wawancara langsung kepada narasumber, pengambilan foto, pencatatan data dengan observasi.

2) Memilih sumber-sumber yang terbaik.

Hal ini bisa dilakukan dengan menggunakan 3 kriteria pemilihan sumber diatas, yaitu: otoritatif, kebaruan dan akurasi.

\section{c. Location and Access/ Lokasi dan akses}

Pada tahap ini perlu kemampuan untuk menggunakan indeks. Hampir semua informasi yang tersedia didunia ini tersusun dalam indeks, agar memungkinkan untuk ditemukan kembali dengan cepat. Bukubuku teks biasanya memiliki indeks dibagian belakang halamannya. Ensiklopedia, baik umum maupun khusus juga memiliki indeks yang biasanya merupakan volume terakhir dari jajaran semua volumnya. Perpustakaan juga memiliki indeks berupa OPAC (Online Public Access Catalog), begitupun internet dengan search engine-nya.

Dengan kemampuan menggunakan indeks ini, maka pencarian informasi yang tersimpan dalam berbagai sumber informasi dapat dilakukan dengan lebih efektif dan efisien. Adapun subdivisi dari step ini adalah:

1) Mencari sumber-sumber informasi.

Mengenali lokasi sumber-sumber informasi sangat dibutuhkan. Misalnya kemampuan mencari buku yang sesuai dengan menggunakan OPAC dan menggunakan "Boolean" untuk mempersempit, memperluas pencarian melalui indeks elektronik seperti OPAC dan search engine atau meta search engine yang ada.

2) Mencari informasi dalam sumber.

Pengenalan terhadap informasi yang dibutuhkan sangat berperan dalam tahap ini. Hal tersebut dikarenakan tidak semua informasi yang didapatkan dari berbagai macam sumber diperlukan. Sehingga perlu mencari sumber-sumber, serta informasi yang relevan dengan kebutuhan 
d. Use of Information/Menggunakan informasi yang sudah tersedia.

Dalam tahap ini akan ditentukan pemilihan cara yang efektif untuk menyaring dan memeras informasi. Informasi yang banyak jumlahnya tersebut akan menjadi informasi yang terseleksi dan siap dipakai dalam berbagai permasalahan. Subdivisi dari tahap ke empat ini adalah sebabagai berikut:

1) Engagel menangani informasi yang tersimpan, dengan cara membaca, mendengarkan, mewawancarai, mengamati dan mengobservasi informasi tersebut. Perlu beberapa keahlian, seperti note taking dengan menggunakan tehnik seperti cornell, mindmapping. Selain itu juga diperlukan keahlian tehnik untuk membaca, seperti tehnik afiksasi membaca cepat, atau SQ3R (Survei, Questioning, Reading, Recite, Review).

2) Menyarikan informasi yang ada. Hal ini bisa dilakukan dengan menggunakan: kutipan, atau paraphrase dan membuat summary. Dengan menggunakan berbagai cara tersebut dapat diambil dan diidentifikasi bagian-bagian yang benar-benar penting dan relevan dengan permasalahan.

\section{e. Synthesis/Sintesa.}

Dalam step ini, dilakukan penggabungan berbagai informasi yang telah didapatkan dan masih tersebar secara konsep. Subdivisinya adalah:

1) Organise/mengorganisasikan berbagai sumber yang terpisah-pisah menjadi satu bentuk produk/hasil yang sitematis. Untuk itu dalam tahap ini perlu beberapa keahlian, seperti misalnya menulis, membuat "outline" karangan, dan berbagai tips untuk membuat kalimat yang efektif, atau menggunakan ilustrasi dan sebagainya.

2) Presentasi, yaitu menunjukkan, menyebarkan informasi yang tersimpan dalam produk kepada orang lain. Hal ini bisa dilakukan dengan berbagai cara, tergantung konteksnya. Misalnya presentasi powerpoint, data statistic, table, perbandingan, cerita, narasi, bentuk-bentuk sastra seperti puisi, cerpen. Untuk dibutuhkan keahlian penggunaan software pembantu dalam membuat presentasi, seperti powerpoin, flash, movie maker.

\section{f. Evaluasi.}

Dalam tahapan ini, yang diharapkan adalah memberikan penilaian terhadap hasil dan proses yang sudah berhasil dilaluinya. Adapun subdivisi dalam tahapan evaluasi ini adalah meliputi:

1) Evaluasi produk, yaitu evaluasi mengenai bentuk hasil/produk dari kegiatan riset yang dilakukan. Misalnya dengan memperhatikan beberapa pertanyaan seperti: Apakah tulisan kita sudah dapat menjawab pertannyaan di dalam introduction? Apakah pernyataan-pernyataan dan argumentasi kita sudah cukup didukung oleh fakta yang tersimpan dalam berbagai sumber. Apakah sudah cukup grafik, tabel yang kita harus pakai untuk mendukung pendapat kita.

2) Evaluasi proses, yaitu evaluasi yang lebih mengarah pada: cara dan proses pembuatan tulisan tersebut. Beberapa pertanyaan yang bisa membantu dalam evaluasi proses adalah: Kesulitan 
apa yang harus dihadapi saat mengerjakan tugas ini? Langkah yang mana yang paling sulit untuk dikerjakan? Apa yang harus saya ubah dalam mengerjakan proses yang sama seperti ini di waktu yang akan datang?

Model ini tidak hanya dapat digunakan sebagai hirarki berfikir yang sistematis untuk mengerjakan penulisan, tapi dapat digunakan sebagai "problem solving tool" dalam memecahkan setiap masalah yang berkaitan dengan informasi sebagai dasar untuk pengambilan keputusan.(Baskoro. 2009)

\section{Metode Penelitian}

Penelitian ini menggunakan metode penelitian deskriptif. Menurut Nazir (2009) metode deskriptif adalah suatu metode dalam meneliti status sekelompok manusia, suatu objek, suatu set kondisi, suatu sistem pemikiran, ataupun suatu kelas peristiwa pada masa sekarang. Selain itu Menurut Sugiyono (2006) penelitian deskriptif adalah "Penelitian yang dilakukan untuk mengetahui nilai variabel mandiri, baik satu variabel atau lebih (independent) tanpa membuat perbandingan, atau menghubungkan dengan variabel lain."

Pada penelitian ini, penulis hanya memaparkan data yang diperoleh dari responden (dalam hal ini pustakawan Pusat Informasi Ilmiah) melalui kuesioner untuk selanjutnya diinterpretasikan.

Penelitian dilakukan di Pusat Informasi Ilmiah yang berada pada setiap Fakultas di Universitas Jenderal Soedirman Purwokerto. Pelaksanaan penelitian dilakukan dalam bulan Juli sampai dengan bulan Agustus 2015.

Dalam penelitian ini kriteria sampel adalah pegawai Pusat Informasi Ilmiah yang sudah memiliki jabatan fungsional pustakawan dan pegawai yang belum memiliki jabatan pustakawan akan tetapi mempunyai latar belakang pendidikan bidang ilmu perpustakaan, dan atau pernah mengikuti pelatihan, workshop kepustakawanan. Jumlah populasi yang memenuhi kriteria dalam penelitian ini berjumlah 18 orang dan digunakan menjadi sampel penelitian.

\subsection{Jenis dan Sumber Data}

Jenis dan sumber data dalam penelitian ini adalah :

a. Data primer, merupakan data yang diperoleh langsung dari responden melalui kuesioner.

b. Data sekunder, merupakan data yang bersumber dari buku, jurnal, proseding, dan dokumen lain yang mendukung dan berhubungan dalam penelitian ini.

\subsection{Uji Validitas dan Reliabilitas Instrumen}

a. Uji Reliabilitas

Realibilitas menyangkut kepatutan alat ukur (Nazir, 2009) reliabilitas adalah ketepatan atau tingkat presisi suatu ukuran atau alat pengukur. Uji ini dimaksudkan untuk menguji alat ukur literasi informasi pustakawan di Pusat informasi Ilmiah yang berupa kuesioner. 
Uji reliabilitas instrumen dilakukan dengan menggunakan rumus alpha $(\alpha)$, rumus alpha digunakan untuk mencari reliabilitas instrumen yang skornya bukan 1 dan 0.

Rumus alpha sebagai berikut :

$$
\propto=\frac{k}{k-1}\left(1-\frac{\sum S^{2} j}{S^{2} x}\right)
$$

Keterangan :

$\alpha \quad=$ koefisien reliabilitas alpha

$\mathrm{k} \quad=$ jumlah item

$\mathrm{Sj} \quad=$ varians responden untuk item I

$\mathrm{Sx} \quad=$ jumlah varians skor total

Jika alpha $>\mathrm{r}$ tabel maka instrumen dinyatakan reliabel namun jika alpha atau $<\mathrm{r}$ tabel maka instrumen dinyatakan tidak reliabel.

Dalam penelitian ini, uji reliabilitas dilakukan dengan menggunakan program SPSS 16.0 for windows.

b. Validitas

Uji validitas untuk menguji apakah instrumen yang digunakan, dalam hal ini kuesioner memenuhi persyaratan validitas, atau tidak, maka digunakan analisis korelasi Pearson.

$$
r=\frac{n \sum x y-\sum x \cdot \sum y}{\sqrt{\left\{n \sum x^{2}-\left(\sum x\right)^{2}\right\}\left\{n \sum y^{2}-\left(\sum y\right)^{2}\right\}}}
$$

Keterangan

rxy $\quad=$ korelasi antara variabel $\mathrm{x}$ dan $\mathrm{y}$

$\mathrm{x} \quad=$ jumlah jawaban item

$\mathrm{y} \quad=$ jumlah item keseluruhan

$\mathrm{n} \quad=$ jumlah responden

Uji validitas dilakukan pada setiap butir pertanyaan, dan hasilnya dapat dilihat melalui hasil $r$-hitung yang dibandingkan dengan $r$-tabel, jika $r_{\text {tabel }}<r_{\text {hitung }}$ maka valid dan jika $r_{\text {tabel }}>r_{\text {hitung }}$ maka tidak valid.

Dalam penelitian ini, uji validitas dilakukan dengan menggunakan bantuan program SPSS 16.0 for windows.

c. Teknik analisis data

Untuk menganalisa hasil kuesioner dan mengetahui bagaimana sikap tiap responden yang menggunakan skala likert, maka dibuat rentang skor dengan langkah sebagai berikut

1) Menentukan skor maksimal, yaitu skor jawaban terbesar di kali banyak item pertanyaan.

2) Menentukan skor minimal, yaitu skor jawaban terkecil dikali banyak item.

3) Menentukan nilai median, yaitu hasil penjumlahan skor maksimal dengan skor minimal dibagi dua. 
4) Menentukan nilai kuartil 1, yaitu hasil penjumlahan skor minimal dengan median dibagi dua.

5) Menentukan nilai kuartil 3, yaitu hasil penjumlahan skor maksimal dengan median dibagi dua.

6) Buatlah skala yang menggambarkan skor minimal, nilai kuartil 1, median, kuartil 3 dan skor maksimal.

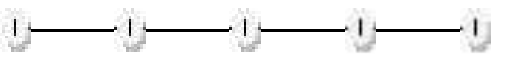

7) $\mathrm{M}_{\text {เe: }} \mathrm{K}_{11} \mathrm{M}_{\text {sk }} \mathrm{K}$ u. ${ }^{\mathrm{Ma}}$ g-masing kategori sikap.

Tabel 3.1 Rentang Kategori Sikap

Sumber: Januari. M. 2014

\begin{tabular}{|c|c|}
\hline KATEGORI SIKAP & RENTANG SKOR \\
\hline Sangat terampil & Kuartil $3 \leq \mathrm{x} \leq$ Skor Maksimal \\
\hline Terampil & Median $\leq \mathrm{x}<$ Kuartil 3 \\
\hline Cukup terampil & Kuartil $1 \leq \mathrm{x}<$ Median \\
\hline Kurang terampil & Skor Minimal $\leq \mathrm{x}<$ Kuartil 1 \\
\hline
\end{tabular}

Data yang diperoleh ditabulasi dengan menyusun ke dalam tabel kemudian dihitung total hasil skor. Hasil penghitungan total skor kemudian di kategorikan berdasarkan tabel kategori sikap dan dihitung persentasenya. Hasil persentase selanjutnya dianalisis dan diinterpretasikan. Penghitungan persentase dalam penelitian ini menggunakan rumus sebagai berikut:

$\mathrm{P} \quad=\mathrm{F} / \mathrm{n}$

Keterangan:

$\mathrm{P} \quad=$ Persentase

$\mathrm{F} \quad=$ Jumlah jawaban yang diperoleh

$\mathrm{N} \quad=$ Jumlah responden (Hadi, 1981)

Untuk menafsirkan besarnya persentase yang didapat dari tabulasi data, penulis menggunakan Metode Supardi (1979) yaitu:

$1-25 \%$ Sebagian kecil

26-49\% Hampir setengah

$50 \%$ Setengah

$51-75 \%$ Sebagian besar

76-99\% Pada umumnya

$100 \%$ Seluruhnya 


\section{Hasil dan Pembahasan}

\subsection{Hasil Uji Validitas dan Reliabilitas}

a. Uji Validitas

Uji validitas terhadap instrumen dalam kuesioner penelitian dilakukan menggunakan SPSS ver 16.0 for windows diperoleh hasil sebagai berikut,

Tabel 4.1 Hasil Uji Validitas

\begin{tabular}{|c|c|c|c|}
\hline No & \multicolumn{1}{|c|}{$\mathrm{r}_{\mathrm{xy}}$} & \multicolumn{1}{|c|}{$\mathrm{r}_{\text {tabel }}$} & Ket \\
\hline 1 & 0,565 & 0,468 & valid \\
\hline 2 & 0,516 & 0,468 & valid \\
\hline 3 & 0,572 & 0,468 & valid \\
\hline 4 & 0,651 & 0,468 & valid \\
\hline 5 & 0,555 & 0,468 & valid \\
\hline 6 & 0,582 & 0,468 & valid \\
\hline 7 & 0,502 & 0,468 & valid \\
\hline 8 & 0,502 & 0,468 & valid \\
\hline 9 & 0,349 & 0,468 & tidak valid \\
\hline 10 & 0,685 & 0,468 & valid \\
\hline 11 & 0,130 & 0,468 & tidak valid \\
\hline 12 & 0,463 & 0,468 & tidak valid \\
\hline & & & \\
\hline
\end{tabular}

\begin{tabular}{|c|c|c|c|}
\hline No & rxy & $\mathrm{r}$ tabel & Ket \\
\hline 13 & 0,720 & 0,468 & valid \\
\hline 14 & 0,713 & 0,468 & valid \\
\hline 15 & 0,677 & 0,468 & valid \\
\hline 16 & 0,580 & 0,468 & valid \\
\hline 17 & 0,717 & 0,468 & valid \\
\hline 18 & 0,508 & 0,468 & valid \\
\hline 19 & 0,462 & 0,468 & tidak valid \\
\hline 20 & 0,520 & 0,468 & valid \\
\hline 21 & 0,578 & 0,468 & valid \\
\hline 22 & 0,530 & 0,468 & valid \\
\hline 23 & 0,410 & 0,468 & tidak valid \\
\hline
\end{tabular}

Diketahui bahwa nilai $\mathrm{r}_{\text {hitung }}$ lebih besar dari $\mathrm{r}_{\text {tabel }}$, artinya istrumen dalam kuesioner dinyatakan valid dan bisa dijadikan sebagai alat pengumpul data dalam penelitian.

b. Uji Reliabilitas

Hasil uji reliabilitas dengan menggunakan SPSS ver 16.0 for windows terhadap instrumen yang digunakan dalam kuesioner penelitian ini menunjukan nilai Alpha sebesar 0,888, kemudian nilai tersebut dibandingkan dengan nilai $\mathrm{r}_{\text {tabel }}$ dengan nilai $\mathrm{N}=18$ pada distribusi nilai $\mathrm{r}_{\text {tabel }}$ signifikansi $5 \%$ diperoleh nilai $\mathrm{r}_{\text {tabel }}$ sebesar 0,468. 
Tabel 4.2 Hasil Uji Reliabilitas Alpha

\section{Reliability Statistics}

\begin{tabular}{|r|r|}
\hline Cronbach's Alpha & $\begin{array}{c}\text { N of } \\
\text { Items }\end{array}$ \\
\hline .888 & 23 \\
\hline
\end{tabular}

Perbandingan tersebut menunjukan bahwa nilai Alpha lebih besar dari $\mathrm{r}_{\text {tabel }}$, maka dapat disimpulkan bahwa instrumen dalam kuesioner dinyatakan reliabel atau konsisten.

\subsection{Analisis 6 Keterampilan The Big6}

The Big6 terdiri dari 6 (enam) keterampilan dan 12 langkah (setiap keterampilan terdiri dari 2 langkah), dalam kuesioner masing masing keterampilan diwakili dengan item pertanyaan guna mengukur keterampilan literasi informasi. Hasil kuesioner tersebut dianalisis dengan menggunakan metode deskriptif, serta ditabulasi dengan menyusun ke dalam tabel kemudian dihitung persentasenya, selanjutnya dianalisis dan diinterpretasikan, hasilnya adalah sebagai berikut.

\section{a. Definisi Masalah}

Keterampilan ke 1 definisi masalah dalam model The Big6 terdiri dari 5 (lima) pertanyaan sehingga didapatkan skala yang menggambarkan skor minimal, nilai kuartil 1, median, kuartil 3 dan skor maksimal yang disajikan dalam tabel berikut ini,

Tabel 4.3 Skala Skor Kuesioner Keterampilan 1 Definisi Masalah

\begin{tabular}{|c|c|c|}
\hline SKALA & PENGHITUNGAN & HASIL \\
\hline Skor maksimal & $4 \times 5$ & 20 \\
\hline Skor minimal & $1 \times 5$ & 5 \\
\hline Median & $(20+5) / 2$ & 12,5 \\
\hline Kuartil 1 & $(5+12,5) / 2$ & 8,75 \\
\hline Kuartil 3 & $(20+12,5) / 2$ & 16,25 \\
\hline
\end{tabular}

Hasil dari skala skor dipergunakan untuk menentukan batas skor untuk masing-masing kategori sikap yang disajikan dalam tabel berikut ini,

Tabel 4.4 Batas Skor Kategori Sikap Kuesioner Keterampilan 1 Definisi Masalah

\begin{tabular}{|c|c|c|}
\hline $\begin{array}{l}\text { KATEGORI } \\
\text { SIKAP }\end{array}$ & ULASAN & $\begin{array}{l}\text { BATAS } \\
\text { SKOR }\end{array}$ \\
\hline Sangat terampil & $\begin{array}{l}\text { Kuartil } 3 \leq \mathrm{x} \leq \text { Skor } \\
\text { Maksimal }\end{array}$ & $16-20$ \\
\hline Terampil & Median $\leq \mathrm{x}<$ Kuartil 3 & $12-15$ \\
\hline Cukup terampil & Kuartil $1 \leq \mathrm{x}<$ Median & $9-11$ \\
\hline Kurang terampil & Skor Minimal $\leq \mathrm{x}<$ Kuartil 1 & $5-8$ \\
\hline
\end{tabular}


Hasil penyebaran kuesioner pada keterampilan 1 diperoleh hasil sebagai berikut :

Tabel 4.5 Rekapitulasi Kategori Sikap Kuesioner Keterampilan 1 Definisi Masalah

\begin{tabular}{|c|c|c|c|}
\hline \multicolumn{4}{|c|}{ REKAPITULASI } \\
\hline KATEGORI & $\begin{array}{c}\text { KATEGORI } \\
\text { SKOR }\end{array}$ & FREKUENSI & PERSENTASE \\
\hline $\begin{array}{c}\text { Sangat } \\
\text { terampil }\end{array}$ & $16-20$ & 8 & $44 \%$ \\
\hline Terampil & $12-15$ & 7 & $39 \%$ \\
\hline $\begin{array}{c}\text { Cukup } \\
\text { terampil }\end{array}$ & $9-11$ & 2 & $11 \%$ \\
\hline $\begin{array}{c}\text { Kurang } \\
\text { terampil }\end{array}$ & $5-8$ & 1 & $6 \%$ \\
\hline TOTAL & & 18 & $100 \%$ \\
\hline
\end{tabular}

Jumlah skor kuesioner selanjutnya dianalisis berdasarkan batas skor kategori sikap serta di persentasekan untuk menentukan keterampilan literasi informasi pustakawan. Dalam tabel 4.5 menunjukkan bahwa 44\% sangat terampil, 39\% terampil, 11\% cukup terampil, dan $6 \%$ kurang terampil. Persentase kemudian ditafsirkan besarnya menggunakan Metode Supardi (1979). Persentase terbesar $44 \%$ berada pada rentang tafsiran antara $26-49 \%$, sehingga dapat dikatakan bahwa hampir setengah pustakawan memiliki keterampilan dalam mendefinisikan masalah.

\section{b. Strategi Pencarian Informasi}

Keterampilan ke 2 strategi pencarian informasi dalam model The Big6 terdiri dari 4 (empat) pertanyaan sehingga didapatkan skala yang menggambarkan skor minimal, nilai kuartil 1, median, kuartil 3 dan skor maksimal yang disajikan dalam tabel berikut ini,

Tabel 4.6 Skala Skor Kuesioner Keterampilan 2 Strategi Pencarian Informasi

\begin{tabular}{|c|c|c|}
\hline SKALA & PENGHITUNGAN & HASIL \\
\hline Skor maksimal & $4 \times 4$ & 16 \\
\hline Skor minimal & $1 \times 4$ & 4 \\
\hline Median & $(16+4) / 2$ & 10 \\
\hline Kuartil 1 & $(4+10) / 2$ & 7 \\
\hline Kuartil 3 & $(16+10) / 2$ & 13 \\
\hline
\end{tabular}

Hasil dari skala skor dipergunakan untuk menentukan batas skor untuk masing-masing kategori sikap yang disajikan dalam tabel berikut ini, 
Tabel 4.7 Batas Skor Kategori Sikap Kuesioner Keterampilan 2 Strategi Pencarian Informasi

\begin{tabular}{|l|l|c|}
\hline \multicolumn{1}{|c|}{$\begin{array}{c}\text { KATEGORI } \\
\text { SIKAP }\end{array}$} & \multicolumn{1}{|c|}{ ULASAN } & BATAS SKOR \\
\hline Sangat terampil & $\begin{array}{l}\text { Kuartil 3 } \leq \mathrm{x} \leq \text { Skor } \\
\text { Maksimal }\end{array}$ & $13-16$ \\
\hline Terampil & Median $\leq \mathrm{x}<$ Kuartil 3 & $10-12$ \\
\hline Cukup terampil & Kuartil 1 $\leq \mathrm{x}<$ Median & $7-9$ \\
\hline Kurang terampil & $\begin{array}{l}\text { Skor Minimal } \leq \mathrm{x}< \\
\text { Kuartil 1 }\end{array}$ & $4-6$ \\
\hline
\end{tabular}

Hasil penyebaran kuesioner pada keterampilan 2 diperoleh hasil sebagai berikut :

Tabel 4.8 Rekapitulasi Kategori Sikap Kuesioner Keterampilan 2 Strategi Pencarian Informasi

\begin{tabular}{|l|c|c|c|}
\hline \multicolumn{4}{|c|}{ REKAPITULASI } \\
\hline KATEGORI & $\begin{array}{c}\text { KATEGORI } \\
\text { SKOR }\end{array}$ & FREKUENSI & PERSENTASE \\
\hline Sangat terampil & $13-16$ & 6 & $33 \%$ \\
\hline Terampil & $10-12$ & 10 & $56 \%$ \\
\hline Cukup terampil & $7-9$ & 2 & $11 \%$ \\
\hline $\begin{array}{l}\text { Kurang } \\
\text { terampil }\end{array}$ & $4-6$ & 0 & $0 \%$ \\
\hline \multicolumn{1}{|c|}{ TOTAL } & & 18 & $100 \%$ \\
\hline
\end{tabular}

Jumlah skor kuesioner selanjutnya dianalisa berdasarkan batas skor kategori sikap serta di persentasekan untuk menentukan keterampilan literasi informasi pustakawan. Dalam tabel 4.8 menunjukkan bahwa 33\% sangat terampil, 56\% terampil, dan $11 \%$ cukup terampil. Persentase kemudian ditafsirkan besarnya menggunakan Metode Supardi (1979). Persentase terbesar 56\% berada pada rentang tafsiran antara 51-75\%, sehingga dapat dikatakan bahwa sebagian besar pustakawan memiliki keterampilan strategi pencarian informasi.

c. Menemukan Lokasi Akses

Keterampilan ke 3 lokasi akses dalam model The Big6 terdiri dari 4 (empat) pertanyaan sehingga didapatkan skala yang menggambarkan skor minimal, nilai kuartil 1, median, kuartil 3 dan skor maksimal yang disajikan dalam tabel berikut ini, 
Tabel 4.9 Skala Skor Kuesioner Keterampilan 3 Lokasi Akses

\begin{tabular}{|c|c|c|}
\hline SKALA & PENGHITUNGAN & HASIL \\
\hline Skor maksimal & $4 \times 4$ & 16 \\
\hline Skor minimal & $1 \times 4$ & 4 \\
\hline Median & $(16+4) / 2$ & 10 \\
\hline Kuartil 1 & $(4+10) / 2$ & 7 \\
\hline Kuartil 3 & $(16+10) / 2$ & 13 \\
\hline
\end{tabular}

Hasil dari skala skor dipergunakan untuk menentukan batas skor untuk masing-masing kategori sikap yang disajikan dalam tabel berikut ini,

Tabel 4.10 Batas Skor Kategori Sikap Kuesioner Keterampilan 3 Lokasi Akses

\begin{tabular}{|l|l|c|}
\hline \multicolumn{1}{|c|}{$\begin{array}{c}\text { KATEGORI } \\
\text { SIKAP }\end{array}$} & \multicolumn{1}{|c|}{ ULASAN } & BATAS SKOR \\
\hline Sangat terampil & $\begin{array}{l}\text { Kuartil 3 } \leq \mathrm{x} \leq \text { Skor } \\
\text { Maksimal }\end{array}$ & $13-16$ \\
\hline Terampil & Median $\leq \mathrm{x}<$ Kuartil 3 & $10-12$ \\
\hline Cukup terampil & Kuartil $1 \leq \mathrm{x}<$ Median & $7-9$ \\
\hline Kurang terampil & $\begin{array}{l}\text { Skor Minimal } \leq \mathrm{x}<\text { Kuartil } \\
1\end{array}$ & $4-6$ \\
\hline
\end{tabular}

Hasil penyebaran kuesioner pada keterampilan 3 diperoleh hasil sebagai berikut :

Tabel 4.11 Rekapitulasi Kategori Sikap Kuesioner Keterampilan 3 Lokasi Akses

\begin{tabular}{|l|c|c|c|}
\hline \multicolumn{4}{|c|}{ REKAPITULASI } \\
\hline KATEGORI & $\begin{array}{c}\text { KATEGORI } \\
\text { SKOR }\end{array}$ & FREKUENSI & $\begin{array}{c}\text { PERSENT } \\
\text { ASE }\end{array}$ \\
\hline Sangat terampil & $13-16$ & 9 & $50 \%$ \\
\hline Terampil & $10-12$ & 9 & $50 \%$ \\
\hline Cukup terampil & $7-9$ & 0 & $0 \%$ \\
\hline Kurang terampil & $4-6$ & 0 & $0 \%$ \\
\hline \multicolumn{1}{|c|}{ TOTAL } & & 18 & $100 \%$ \\
\hline
\end{tabular}

Jumlah skor kuesioner selanjutnya di analisa berdasarkan batas skor kategori sikap serta di persentasekan untuk menentukan keterampilan literasi informasi pustakawan. Dalam tabel 4.11 menunjukkan bahwa 50\% sangat terampil, dan 50\% terampil. Persentase kemudian ditafsirkan besarnya menggunakan Metode Supardi (1979). Persentase terbesar 50\% berada pada tafsiran 50\%, sehingga dapat dikatakan bahwa setengah pustakawan Pusat Informasi Ilmiah Unsoed memiliki keterampilan strategi pencarian informasi. 
d. Menggunakan Informasi

Keterampilan ke 4 mengunakan informasi dalam model The Big6 terdiri dari 4 (empat) pertanyaan sehingga didapatkan skala yang menggambarkan skor minimal, nilai kuartil 1, median, kuartil 3 dan skor maksimal yang disajikan dalam tabel berikut ini,

Tabel 4.12 Skala Skor Kuesioner Keterampilan 4 Mengunakan Informasi

\begin{tabular}{|c|c|c|}
\hline SKALA & PENGHITUNGAN & HASIL \\
\hline Skor maksimal & $4 \times 4$ & 16 \\
\hline Skor minimal & $1 \times 4$ & 4 \\
\hline Median & $(16+4) / 2$ & 10 \\
\hline Kuartil 1 & $(4+10) / 2$ & 7 \\
\hline Kuartil 3 & $(16+10) / 2$ & 13 \\
\hline
\end{tabular}

Hasil dari skala skor dipergunakan untuk menentukan batas skor untuk masing-masing kategori sikap yang disajikan dalam tabel berikut ini,

Tabel 4.13 Batas Skor Kategori Sikap Kuesioner Keterampilan 4 Mengunakan Informasi

\begin{tabular}{|l|l|c|}
\hline \multicolumn{1}{|c|}{$\begin{array}{c}\text { KATEGORI } \\
\text { SIKAP }\end{array}$} & \multicolumn{1}{c|}{ ULASAN } & BATAS SKOR \\
\hline Sangat terampil & $\begin{array}{l}\text { Kuartil 3 } \leq \mathrm{x} \leq \\
\text { Skor Maksimal }\end{array}$ & $13-16$ \\
\hline Terampil & $\begin{array}{l}\text { Median } \leq \mathrm{x}< \\
\text { Kuartil 3 }\end{array}$ & $10-12$ \\
\hline Cukup terampil & $\begin{array}{l}\text { Kuartil 1 } \leq \mathrm{x}< \\
\text { Median }\end{array}$ & $7-9$ \\
\hline Kurang terampil & $\begin{array}{l}\text { Skor Minimal } \leq \mathrm{x} \\
<\text { Kuartil 1 }\end{array}$ & $4-6$ \\
\hline
\end{tabular}

Hasil penyebaran kuesioner pada keterampilan 4 diperoleh hasil sebagai berikut :

Tabel 4.14 Rekapitulasi Kategori Sikap Kuesioner Keterampilan 4 Mengunakan Informasi

\begin{tabular}{|l|c|c|c|}
\hline \multicolumn{4}{|c|}{ REKAPITULASI } \\
\hline KATEGORI & $\begin{array}{c}\text { KATEGORI } \\
\text { SKOR }\end{array}$ & FREKUENSI & PERSENTASE \\
\hline $\begin{array}{l}\text { Sangat } \\
\text { terampil }\end{array}$ & $13-16$ & 6 & $33 \%$ \\
\hline Terampil & $10-12$ & 6 & $33 \%$ \\
\hline $\begin{array}{l}\text { Cukup } \\
\text { terampil }\end{array}$ & $7-9$ & 5 & $28 \%$ \\
\hline $\begin{array}{l}\text { Kurang } \\
\text { terampil }\end{array}$ & $4-6$ & 1 & $6 \%$ \\
\hline \multicolumn{1}{|c|}{ TOTAL } & & 18 & $100 \%$ \\
\hline
\end{tabular}

Jumlah skor kuesioner selanjutnya di analisa berdasarkan batas skor kategori sikap serta di persentasekan untuk menentukan keterampilan literasi informasi pustakawan. Dalam tabel 4.14 
menunjukkan bahwa 33\% sangat terampil, 33\% terampil, $28 \%$ cukup terampil, dan $6 \%$ kurang terampil. Persentase kemudian ditafsirkan besarnya menggunakan Metode Supardi (1979). Persentase terbesar $33 \%$ berada pada rentang tafsiran antara $26-49 \%$, sehingga dapat dikatakan bahwa hampir setengah pustakawan memiliki keterampilan menggunakan informasi atau memiliki cara yang efektif untuk menyaring dan memeras informasi.

e. Sintesis

Keterampilan ke 5 sintesis dalam model The Big6 terdiri dari 4 (empat) pertanyaan sehingga didapatkan skala yang menggambarkan skor minimal, nilai kuartil 1, median, kuartil 3 dan skor maksimal yang disajikan dalam tabel berikut ini,

Tabel 4.15 Skala Skor Kuesioner Keterampilan 5 Sintesis

\begin{tabular}{|c|c|c|}
\hline SKALA & PENGHITUNGAN & HASIL \\
\hline Skor maksimal & $4 \times 5$ & 20 \\
\hline Skor minimal & $1 \times 5$ & 5 \\
\hline Median & $(20+5) / 2$ & 12,5 \\
\hline Kuartil 1 & $(5+12,5) / 2$ & 8,75 \\
\hline Kuartil 3 & $(20+12,5) / 2$ & 16,25 \\
\hline
\end{tabular}

Hasil dari skala skor dipergunakan untuk menentukan batas skor untuk masing-masing kategori sikap yang disajikan dalam tabel berikut ini,

Tabel 4.16 Batas Skor Kategori Sikap Kuesioner Keterampilan 5 Sintesis

\begin{tabular}{|l|l|c|}
\hline $\begin{array}{l}\text { KATEGORI } \\
\text { SIKAP }\end{array}$ & \multicolumn{1}{|c|}{ ULASAN } & BATAS SKOR \\
\hline $\begin{array}{l}\text { Sangat } \\
\text { terampil }\end{array}$ & $\begin{array}{l}\text { Kuartil } 3 \leq \mathrm{x} \leq \text { Skor } \\
\text { Maksimal }\end{array}$ & $16-20$ \\
\hline Terampil & $\begin{array}{l}\text { Median } \leq \mathrm{x}< \\
\text { Kuartil } 3\end{array}$ & $12-15$ \\
\hline $\begin{array}{l}\text { Cukup } \\
\text { terampil }\end{array}$ & $\begin{array}{l}\text { Kuartil } 1 \leq \mathrm{x}< \\
\text { Median }\end{array}$ & $9-11$ \\
\hline $\begin{array}{l}\text { Kurang } \\
\text { terampil }\end{array}$ & $\begin{array}{l}\text { Skor Minimal } \leq \mathrm{x}< \\
\text { Kuartil 1 }\end{array}$ \\
\hline
\end{tabular}

Hasil penyebaran kuesioner pada keterampilan 5 diperoleh hasil sebagai berikut : 
Tabel 4.17 Rekapitulasi Kategori Sikap Kuesioner Keterampilan 5 Sintesis

\begin{tabular}{|l|c|c|c|}
\hline \multicolumn{4}{|c|}{ REKAPITULASI } \\
\hline KATEGORI & $\begin{array}{c}\text { KATEGORI } \\
\text { SKOR }\end{array}$ & FREKUENSI & PERSENTASE \\
\hline $\begin{array}{l}\text { Sangat } \\
\text { terampil }\end{array}$ & $16-20$ & 3 & $17 \%$ \\
\hline Terampil & $12-15$ & 11 & $61 \%$ \\
\hline $\begin{array}{l}\text { Cukup } \\
\text { terampil }\end{array}$ & $9-11$ & 4 & $22 \%$ \\
\hline $\begin{array}{l}\text { Kurang } \\
\text { terampil }\end{array}$ & $5-8$ & 0 & $0 \%$ \\
\hline \multicolumn{1}{|c|}{ TOTAL } & 18 & $100 \%$ \\
\hline
\end{tabular}

Jumlah skor kuesioner selanjutnya di analisa berdasarkan batas skor kategori sikap serta di persentasekan untuk menentukan keterampilan literasi informasi pustakawan. Dalam tabel 4.17 menunjukkan bahwa 17\% sangat terampil, $61 \%$ terampil, dan $22 \%$ cukup terampil. Persentase kemudian ditafsirkan besarnya menggunakan Metode Supardi (1979). Persentase terbesar 61\% berada rentang tafsiran antara 51-75\%, sehingga dapat dikatakan bahwa sebagian besar pustakawan memiliki keterampilan sintesis atau menggabungkan berbagai informasi yang telah didapatkan dan masih tersebar secara konsep.

\section{f. Evaluasi}

Keterampilan ke 6 evaluasi dalam model The Big6 terdiri dari 2 (dua) pertanyaan sehingga didapatkan skala yang menggambarkan skor minimal, nilai kuartil 1, median, kuartil 3 dan skor maksimal yang disajikan dalam tabel berikut ini,

Tabel 4.18 Skala Skor Kuesioner Keterampilan 6 Evaluasi

\begin{tabular}{|c|c|c|}
\hline SKALA & PENGHITUNGAN & HASIL \\
\hline $\begin{array}{c}\text { Skor } \\
\text { maksimal }\end{array}$ & $4 \times 2$ & 8 \\
\hline Skor minimal & $1 \times 2$ & 2 \\
\hline Median & $(8+2) / 2$ & 5 \\
\hline Kuartil 1 & $(2+5) / 2$ & 3,5 \\
\hline Kuartil 3 & $(8+5) / 2$ & 6,5 \\
\hline
\end{tabular}

Hasil dari skala skor dipergunakan untuk menentukan batas skor untuk masing-masing kategori sikap yang disajikan dalam tabel berikut ini, 
Tabel 4.19 Batas Skor Kategori Sikap Kuesioner Keterampilan 6 Evaluasi

\begin{tabular}{|l|l|c|}
\hline $\begin{array}{c}\text { KATEGORI } \\
\text { SIKAP }\end{array}$ & \multicolumn{1}{|c|}{ ULASAN } & BATAS SKOR \\
\hline $\begin{array}{l}\text { Sangat } \\
\text { terampil }\end{array}$ & $\begin{array}{l}\text { Kuartil 3 } \leq \mathrm{x} \leq \text { Skor } \\
\text { Maksimal }\end{array}$ & $6-8$ \\
\hline Terampil & $\begin{array}{l}\text { Median } \leq \mathrm{x}< \\
\text { Kuartil 3 }\end{array}$ \\
\hline $\begin{array}{l}\text { Cukup } \\
\text { terampil }\end{array}$ & $\begin{array}{l}\text { Kuartil } 1 \leq \mathrm{x}< \\
\text { Median }\end{array}$ & $3-4$ \\
\hline $\begin{array}{l}\text { Kurang } \\
\text { terampil }\end{array}$ & $\begin{array}{l}\text { Skor Minimal } \leq \mathrm{x}< \\
\text { Kuartil 1 }\end{array}$ \\
\hline
\end{tabular}

Hasil penyebaran kuesioner pada keterampilan 6 diperoleh hasil sebagai berikut :

Tabel 4.20 Rekapitulasi Kategori Sikap Kuesioner Keterampilan 6 Evaluasi

\begin{tabular}{|l|c|c|c|}
\hline \multicolumn{4}{|c|}{ REKAPITULASI } \\
\hline KATEGORI & $\begin{array}{c}\text { KATEGORI } \\
\text { SKOR }\end{array}$ & FREKUENSI & PERSENTASE \\
\hline $\begin{array}{l}\text { Sangat } \\
\text { terampil }\end{array}$ & $6-8$ & 11 & $61 \%$ \\
\hline Terampil & 5 & 3 & $17 \%$ \\
\hline $\begin{array}{l}\text { Cukup } \\
\text { terampil }\end{array}$ & $3-4$ & 4 & $22 \%$ \\
\hline $\begin{array}{l}\text { Kurang } \\
\text { terampil }\end{array}$ & 2 & 0 & $0 \%$ \\
\hline TOTAL & & 18 & $100 \%$ \\
\hline
\end{tabular}

Jumlah skor kuesioner selanjutnya di analisa berdasarkan batas skor kategori sikap serta di persentasekan untuk menentukan keterampilan literasi informasi pustakawan. Dalam tabel 4.20 menunjukkan bahwa $61 \%$ sangat terampil, $17 \%$ terampil, dan $22 \%$ cukup terampil. Persentase kemudian ditafsirkan besarnya menggunakan Metode Supardi (1979). Persentase terbesar 61\% berada rentang tafsiran antara 51-75\%, sehingga dapat dikatakan bahwa sebagian besar pustakawan memiliki keterampilan dalam memberikan penilaian terhadap hasil dan proses yang sudah berhasil dilaluinya.

\section{Penutup}

\subsection{Simpulan dan Rekomendasi}

Berdasarkan hasil penelitian ini pustakawan Pusat Informasi Ilmiah di Universitas Jenderal Soedirman sudah memiliki keterampilan literasi informasi. Hal tersebut nampak dari hasil rekapitulasi kategori sikap yang rata-rata berada pada sikap sangat terampil dan terampil. Persentase terbesar kategori sikap sangat terampil berada pada keterampilan sintesis atau menggabungkan berbagai informasi ditandai $61 \%$ dan keterampilan memberikan penilaian terhadap hasil dan proses yang sudah 
berhasil dilalui ditandai $61 \%$. Sedangkan pesentase terbesar kategori sikap kurang terampil berada pada keterampilan menggunakan informasi hanya ditandai dengan $6 \%$.

Keterampilan literasi informasi yang dimiliki pustakawan Pusat Informasi Ilmiah akan membantu pustakawan dalam memberikan informasi yang relevan dan berkualitas sesuai kebutuhan pemustaka di Universitas Jenderal Soedirman.

Berdasarkan hasil penelitian ini, saran yang disampaikan penulis adalah sebagai berikut:

1. Pustakawan Pusat Informasi Ilmiah di lingkungan Universitas Jenderal Soedirman sudah memiliki keterampilan literasi informasi, sehingga perlu dipertahankan dan dikembangkan guna memberikan informasi yang relevan dan berkualitas sesuai kebutuhan pemustaka.

2. Perlu meningkatkan keterampilan menggunakan informasi karena hasil penelitian menunjukan $6 \%$ pustakawan berada pada kategori sikap kurang terampil.

\section{Daftar Pustaka}

ACRL(Association of College \& Research Libraries). 2000. Information Literacy Competency Standards for Higher Education. diakses pada 23 Juli 2015. <http://www.ala.org/ala/mgr ps/divs/acrl/standards/standardsguidelines.cfm>

Arikunto, Suharsimi. 2006. Prosedur Penelitian: suatu pendekatan praktik. Jakarta: Rineka Cipta

Armstrong, C,et al. 2005. Defining Information Literacy for the UK. diakses pada 23 Juli 2015. http://eprints.rclis.org/7459/

Djaali. 2008. Psikologi Pendidikan. Jakarta : PT. Bumi Aksara

Doyle, Christina. 1992. Outcome measures for information literacy within the national education goals of 1990: final report of the National Forum on Information Literacy. Summary of findings. Washington, DC: US Department of Education. (ERIC documentno;ED351033), diakses pada 23 Juli

http://eric.ed.gov/ERICDocs/data/ericdocs2/content_storage_01/0000000b/80/23/4a/12.pdfl

Gunawan, A.W., dkk. 2008. 7 Langkah Literasi Informasi : Knowledge Management. Jakarta: Universitas Atmajaya

Hadi, Sutrisno. 1981. Metode Research. Yogyakarta: Yayasan Penelitian Fakultas Psikologi UGM

Hancook, V.E. 2004. Information literacy for life long learning, diakses pada 24 Juli 2015. http://www.ericdigest.org/longlife.html

Januari. M. 2014. Skala Pengukuran. Jambi: STKIP YPM Bangko. diakses 30 July 2015 http://s3.amazonaws.com/academia.edu.documents/32297110/Materi_P5_Skala_Pengukuran.pdf? AWSAccessKeyId=AKIAJ56TQJRTWSMTNPEA\&Expires=1438197671\&Signature $=\mathrm{iGzOTbO}$ tGpKcNZrdBooma60w4yU\%3D

Kuhlthau, C.C. 1987. Informatioan Skkills for an information Society : A Riview of research. Syracuse, NY: Eric Clearinghouse on Information Resources. ED 297740 
Naibaho, Kalarensi.2007. "Menciptakan Generasi LiteratMelalui Perpustakaan”. Majalah Visi pustaka vol.9 no.3

Nasution, 2003. Metode Rresearch : penelitian ilmiah. Jakarta: Bumi Aksara

Nazir, Moh. 2009. Metode Penelitian. Jakarta: Ghalia Indonesia

Pendit, Putu Laxman. 2007. Perpustakaan Digital: Perspektif Perpustakaan Perguruan Tinggi Indonesia. Jakarta: CV. Sagung Seto.

Qalyubi,Syihabuddin dkk.2003. Dasar-dasar Ilmu Perpustakaan dan Informasi. Yogyakarta: Jurusan Ilmu Perpustakaan dan Informasi Fak. Adab UIN Sunan Kalijaga

Septiyantono, Tri. 2015. Literasi Informasi. Jakarta : Universitas Terbuka

Steel, Robert G. D. 1933. Prinsip dan Prosedur Statistika : Suatu Pendekatan Biometrik. Jakarta: Gramedia

Sudjana, N dan Ibrahim, 2007. Penelitian dan Penilaian Pendidikan. Bandung: Sinar Baru Algensindo

Sugiyono, 1999. Metode Penelitian Administrasi. Edisi Revisi. Bandung: Alfabeta.

Sulistyo-basuki. 2007 “Kemelekan Informasi”. Seminar dan Pelatihan Kemelekan Informasi UI Model. Banten.

Supardi, A. 1979. Statistik. Bandung: Fakultas Tarbiah IAIN Sunan Gunung Jati

Sutabri, Tata .2005. Sistem Informasi Manajemen. Yogyakarta: ANDI

Wahidaturohmah, Rois. 2014. Studi Literasi informasi Pustakawan Di Perpustakaan Pusat Universitas Gajah Mada Yogyakarta Berdasarkan Model The Big6. Skripsi. Program Studi Ilmu Perpustakaan. Universitas Islam Negeri Sunan Kalijaga, Yogyakarta

Wijayanti, Luki. 2013. Membangun perpustakaan perguruan tinggi masa kini : pengalaman Universitas $\begin{array}{lllll}\text { Indonesia. } & \text { Diakses } & \text { pada } & 29 & \text { Juli }\end{array}$ http://perpustakaan.uns.ac.id/?opt=1001\&menu=news\&option=detail\&nid=382 